Каптелина O.A.

\title{
МОНАРХИЧЕСКИЕ НАСТРОЕНИЯ КРЕСТЬЯН РОССИЙСКОЙ ИМПЕРИИ В НАЧАЛЕ ХХ ВЕКА (ПО МАТЕРИАЛАМ ПИСЕМ В ГЛАВНЫЙ СОВЕТ СОЮЗА РУССКОГО НАРОДА): ИСТОЧНИКОВЕДЧЕСКИЕ ПРОБЛЕМЫ
}

Аниотация: Политические изленения в Российкой империи после революиионных событиий $1905-1907$ г2. ли за собой дифференииацию общественных настроений. Различные социальные группь переживали этот процесс по-своему. Наиболее интересным и малоизученным является вопрос об отношении крестьян к демократическим изменениям, происходивиим в России. Данная статья представляет собой попьтку прояснить настроения крестьян, которые нашли отражение в письмах, адресованных в Союз Русского народа, хранящиися в ГА РФ. В статье рассматриваются вопросы о том, насколько крестьяне придерживались монархических взглядов, каким образом они транслировали свои идеи, каково участие Союза Русского народа в эволючии крестьянского сознания. Автор использует архивные материаль, сосредотачивая внимания на источниковедческих приемах анализа информации, среди которых атрибуцуия и классификация материалов писем, а такжсе частотный анализ. Источниковедческий анализ материалов проводился с точки зрения аутентичного прочтения и интерпретации текстов писем крестьян, анализа их информативной цуенности с целью изучения восприятия крестьянами политической линии Союза Русского народа, а также того, насколько крестьяне разделяли монархические настроения и основополагаюшие идеи данной партии. Анализ крестьянских посланий позволяет говорить не только о том, что крестьяне после револючии 1905-1907 г2. сохраняли монархические установки и разделяли идеи крайне правого политического движения, но и увидеть все оттенки этих настроений. Научная новизна работы заключается во введении в научный оборот архивных материалов и их комплексного исследования.

Review: Political transformations that took place in the Russian Empire after revolutionary events of 1905 - 1907 were followed by the differentiation of public moods. Various social groups experienced the process in different ways. The most interesting and understudied question still remains the question about the attitude of peasants to democratic changes happening in Russia back in those times. The present article presents the attempt of the author to clarify the moods of peasants that were reflected in letters addressed to the Russian People's Union and stored in the State Archive of the Russian Federation. The article deals with the questions about to what extent peasants followed the monarchical views, how they conveyed their ideas and what influence the Russian People's Union had on the evolution of peasant mentality. In her research $O$. Kaptelina studies archives and focuses on methods of information analysis adopted from source studies including attribution and classification of letters as well as the frequency analysis. Source analysis of materials was performed with reference to the authentic interpretation of letters written by peasants and analysis of their informative value for the purpose of studying the perception of the policy of the Russian People's Union by peasants as well as to what degree peasants shared the monarchical moods and basic ideas of the party. The results of the analysis of peasants' letters do not only show that after the revolution of 1905 - 1907 peasants kept to the monarchical policy and shared the ideas of the extreme right-wing political movement but also allow to see all the shades of those moods. The scientific novelty of the research is in introduction of archives and their integrated study into scientific use.

Ключевые слова: Российская империя, револючия, Союз Русского народа, монархические взглядьл, крестьянская ментальность, архивы, Источниковедение, реформы, общественные настроения, социальные группь. Keywords: Russian Empire, revolution, Russian People's Union, monarchical views, peasant mentality, source studies, reforms, public moods, social groups.

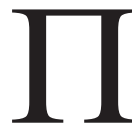

олитические изменения в Российской империи после революционных событий 1905-1907 гг. повлекли за собой дифференциацию общественных настроений. Различ- ные социальные группы переживали этот процесс по-своему. Современники писали о том, что общество переживало перестройку, но перестраивались «не политические понятия и общественные 
интересы, а политические чувства и социальные отношения» ${ }^{1}$. Наиболее интересным и малоизученным является вопрос об отношении крестьян к демократическим изменениям, происходившим в России. Изучение содержания человеческого сознания, реконструкция ментальных установок различных групп и слоев российского общества в переломные эпохи, представляются чрезвычайно актуальными. Отечественная историография накопила опыт в исследовании этих проблем². Однако не все вопросы в отношении общественных настроений и ломки стереотипов в бурные революционные годы решены. Насколько крестьяне, как одна из наиболее многочисленных социальных групп Российской империи, придерживались монархических или демократических установок, каким образом они транслировали свои взгляды, какова роль политических партий в отношении крестьянской социальной группы, как менялись их «политические чувства и политические отношения»? Данная статья представляет собой попытку прояснить некоторые из поставленных вопросов. Реконструкция некоторых важных аспектов содержания массового сознания крестьян в период первой российской революции может быть проведена на материалах архивного фонда Союза русского народа, который в начале ХХ в. являлся наиболее массовой правой партией, численность которой доходила до 400 тыс. членов ${ }^{3}$.

Документация Союза русского народа (далее - СРН), хранящаяся в Государственном архиве Российской Федерации (Ф. 116, ГА РФ), неоднократно использовалась в научных исследованиях ${ }^{4}$.

\footnotetext{
${ }^{1}$ Ключевский В.О. Афоризмы. Исторические портреты и этюды. Дневники. М., 1993. С. 387.

${ }^{2}$ Менталитет и аграрное развитие России (XIX-XX вв.). М., 1996; Революция и человек. Социально-психологический аспект. М., 1996; Менталитет и политическое развитие России. М., 1996; Буховеи О.Г. Социальные конфликты и крестьянская ментальность в Российской империи начала XX века: новые материалы, методы, результаты. М., 1996; Революция и человек: быт, нравы, поведение, мораль. М., 1997; Селунская Н.Б., Тоштендаль Р. Зарождение демократической культуры в России: Россия в начале XX века. М., 2005 и др.

${ }^{3}$ Кирьянов Ю.И. Правые партии в России 1911-1917. М., 2001. C. 83 .

${ }^{4}$ Степанов С.A. Чёрная сотня в России (1905-1914). М., 1992; Кирьянов Ю.И. Правые партии в России 1911-1917. М., 2001.; Кирьянов Ю.И. Русское собрание 1900-1917 гг. М., 2003; Омельянчук И.В. Черносотенное движение в Рос-
}

Однако, рассматриваемые в данной статье комплексы писем граждан в Главный совет СРН и редакцию газеты «Русское знамя», содержащие послания крестьян, систематическому анализу не подвергались, что позволяет говорить о данном источниковом комплексе как о малоизученном. Источниковедческий анализ материалов представляется целесообразным проводить с точки зрения аутентичного прочтения и интерпретации текстов посланий; анализа информативной ценности посланий с целью изучения восприятия крестьянами политической линии СРН, а также того, насколько крестьяне разделяли монархические настроения и основополагающие идеи данной партии.

Архивный фонд СРН состоит из следующих документообразующих комплексов: архив Главного совета; архив Канцелярии Главного совета СРН; комплекс документации Канцелярии Съезда губернских и областных представителей СРН (1907 г.); материалы Распорядительного совета Всероссийского съезда СРН (1911 г.); архив газеты «Русское знамя»; а также личные архивы лидеров партии А.И. Дубровина и Е.А. Полубояриновой.

Фонд СРН содержит комплекс писем, среди которых отложились послания крестьян. Если суммировать данные по всей корреспонденции фонда, то получается в общей сложности 381 послание. При проведении классификации корреспонденции по социальному статусу авторов возможно выделить 30\% посланий из числа атрибутированных, поступивших в Главный совет или в редакцию газеты «Русское знамя» от крестьян ${ }^{5}$. Это свидетельствует о том, что крестьяне достаточно активно обращались в Главный совет СРН и редакцию газеты «Русское знамя», делясь своими мыслями, чувствами, взглядами. Содержание этих писем было подвергнуто тщательному анализу.

Во-первых, интерес вызывают вопрос о восприятии крестьянами Союза русского народа и их отношение к лидерам СРН. Прежде всего необходимо было установить адресатов посланий. Было выяснено, что наибольшее количество кор-

сийской империи (1901 - 1914). Киев, 2006; Русский консерватизм середины XVIII - начала XX века : энциклопедия / Ин-т обществ. мысли ; редкол.: В В. Шелохаев (отв. ред.) [и др.] М., 2010.

${ }^{5}$ Не удалось установить социальный статус $35 \%$ адресатов. 


\section{Политика и общество 8 (116) • 2014}

респонденции написано на имя председателя СРН А.И. Дубровина. Кроме того он был главным редактором газеты «Русское знамя». Далее по представительности идет корреспонденция, адресованная Е.А. Полубояриновой, которая после раскола единой партии была правой рукой А.И. Дубровина в управлении Дубровинского Союза и в издании газеты «Русское знамя».

Текстологический анализ показывает, что крестьяне воспринимали СРН как свою защиту и опору, как партию, способную реально помочь в решении их насущных вопросов. Так, крестьяне Тамбовской губернии обращались в адрес Главного совета СРН в 1914 г. со словами, «как мы слышавшие от нашего крестьянина Максима Шипилова, которому Совет Союза русского народа оказал пристанище и покровительство в делах его, то мы смиренные темные люди решились взять на себя смелость просить заступничества и помощи и утешения в великом нашем горе» ${ }^{6}$.

Во всех посланиях крестьяне демонстрируют крайне уважительное отношение к руководству СРН. Об этом свидетельствуют следующие строки: «Да благословит Вас Всевышний за Вашу доброту, за борьбу правую и любовь Вашу к России, Царю, Глубокоуважаемый Отец и Защитник» ${ }^{7}$.

Кроме того, зачастую крестьяне в СРН видели последний шанс решить свои насущные проблемы, когда все остальные инстанции были уже пройдены, они обращались за помощью и поддержкой в Союз. Ярким примером подобного послания является письмо от крестьян Черниговской губернии, которые прежде чем обратиться в Главный Совет, уже пытались ходатайствовать к Черниговскому губернатору, в Черниговскую Духовную консисторию, к Прокурору Стародубского окружного суда, в Священный Синод. Вопрос их не был разрешен, что и заставило их в итоге просить помощи у Союза: «Просим вас походатайствовать перед Священным Синодом принять надлежащие меры. <..> Почтительно просим защитить нас, а ходатайство ускорить перед надлежащими учреждениями» ${ }^{8}$.

А.И. Дубровина крестьяне воспринимали как важную и влиятельную фигуру, заступника и по-

\footnotetext{
${ }^{6}$ ГА РФ. Ф. 116. Оп. 1. Д. 36. Л. 36.

${ }^{7}$ ГА РФ. Ф. 116. Оп. 1. Д. 604. Л. 23

${ }^{8}$ ГА РФ. Ф. 116. Оп. 1. Д. 35. Л. 283.
}

следнюю надежду. Их голоса доносятся из писем словами: «На вас устремлены взоры истиннорусских людей, вам доверились тысячи русского народа» ${ }^{9}$; «Здравомыслящий народ русский и воинство на Вашей стороне. Вот это есть Ваша забота, заслуга и труды, положенные на алтарь Отечества. Я хоть и маленький человек и то стра даю за вашу идею, но не отступлю и буду впредь присягать» ${ }^{10}$. Русский патриархальный характер проступает в этих строчках.

Крестьяне рассчитывали на силу и влияние СРН и лично А.И. Дубровина даже в таких вопросах, которые относятся к прерогативам верховной власти, которые должен решать сам Император. Например, в рассматриваемом комплексе корреспонденции встречаются ходатайства о помиловании, поступившие со стороны крестьян, осужденных за политические преступления. Объясняется это тем, что крестьяне воспринимали председателя СРН как олицетворение власти, не менее влиятельного деятеля, чем члены правительства или представителя близкого окружения Императора. Приведем в пример эпитеты, которые используют авторы писем: «Начальник истинно русского народа», «Глубокоуважаемый Отец и Защитник», «Всероссийский воевода» ${ }^{11}$, «Высокочтимый и дорогой наш заступник и покровитель!», «Великий богатырь земли Русской! Доблестный Вождь Могущественного СРН!»; «истинный и благородный рыцарь, бесстрашно идущий на защиту бедного крестьянского люда» - вот те обращения, которые встречаются в письмах крестьян по отношению к А.И. Дубровину. Именно в них проступают черты этатизма и патернализма, свойственные российскому менталитету, о чем неоднократно писали исследователи ${ }^{12}$.

Подобные высказывания со стороны крестьян наблюдаются и по отношению к Е.А. Полубояриновой. «Приносим вам глубокую благодарность за доброе отношение к нам, крестьянам, много-

\footnotetext{
${ }^{9}$ ГА РФ. Ф. 116. Оп. 1. Д. 35. Л. 276. Л. 140.

${ }^{10}$ ГА РФ. Ф. 116. Оп. 1. Д. 624. Л. 128

${ }^{11}$ ГА РФ. Ф. 116. Оп. 1. Д. , 35, 36, 604, 624.

${ }^{12}$ Гуревич А.Я. Проблема ментальностей в современной историографии // Всеобщая история: Дискуссии, новые подходы. Вып. 1. М., 1989; Громылко М.М. Мир русской деревни. М., 1991; Касьянова К. О русском национальном характере. М., 1994; Морозов Н. Менталитет русских: понятие, структура // Вестник российской нации. 2012. Т.1. Вып. 21. С. 67-88 и др.
} 
много раз мы тревожим и надоедаем Вам своим делом, не гнушались нами бедным крестьянством, делом, словом, советом не оставляя нас, Бескорыстная Благодетельница» ${ }^{13}$; «Вы глава, основательница сильного могучего Союза русского народа» ${ }^{14}$ - так обращаются ко второму лидеру СРН крестьяне, авторы писем.

Учитывая все выше сказанное, можно говорить о том, что СРН и его руководство пользовались несомненным уважением и авторитетом среди тех крестьян, которые обращались в Союз. Некоторым образом произошел сдвиг в крестьянском сознании, разочаровавшемся в верховной власти или в возможности решить с ее помощью свои проблемы и переложившем «бремя заступничества» на другие плечи. Будучи не в состоянии жить без защиты, многие из них видели в СРН новую опору, рассчитывали на поддержку со стороны его лидеров.

Проведя анализ текстов посланий, направленных крестьянами в Главный Совет СРН и в редакцию газеты «Русское знамя», можно понять, какие именно проблемы и вопросы заставляли корреспондентов писать в Союз. С этой целью необходимо провести тематическую классификацию жалоб, ходатайств и предложений, обнаруженных в письмах и посчитать частоту их встречаемости во всей совокупности комплекса переписки. Затем, выстраивая их по убыванию частоты встречаемости, мы получаем следующие проблемы: имущественные и земельные споры; ходатайства о помиловании; жалобы на «разгул революции» и гонения монархистов в регионах; ходатайства о получении личной аудиенции у Императора; прошения о помощи в строительстве храмов и школ.

Более половины крестьянских прошений написаны в связи с имущественными и земельными спорами и проблемами, среди которых выделяются жалобы на землеустроительные работы; споры, связанными с желанием крестьян докупить еще земли, которая была им необходима из-за общего крестьянского малоземелья или же с просьбами помочь в связи с уже полученным отказом в кредите от Крестьянского банка; имущественными спорами личного характера (например, тяжбы за наследство); спорами между крестьянами и помещиками; жалобами на мошенничество с имуществом; жалобами

\footnotetext{
${ }^{13}$ ГА РФ. Ф. 116. Оп. 1. Д. 36. Л. 118

${ }^{14}$ ГА РФ. Ф. 116. Оп. 1. Д. 36. Л.39.
}

на местные власти в имущественных вопросах. Так, например, письмо крестьянина Саратовской губернии, направленное в редакцию газеты «Русское знамя» на имя А.И. Дубровина, с обвинениями местного волостного старшины в вымогательстве взяток с крестьян в обмен на разрешение на землепользование $^{15}$. Еще одним примером подобного послания является ходатайство крестьян Черниговской губернии: «Благодаря недобросовестности душеприказчиков имение, которое хотели купить крестьяне и на земле которого работали, против воли завещательницы было продано евреям за низшую сумму денег и нас крестьян, нуждающихся в земле, лишили возможности приобрести раньше принадлежащие нам имение» ${ }^{16}$. Можно утверждать, что аграрный вопрос, самый больной вопрос для крестьян мог быть решен СРН. Именно так понимали политическую платформу Союза крестьяне.

Рассмотрев тематику писем, определив причины обращений крестьян в Главный совет СРН, отметим, что второй по частоте группой являются послания, содержащие ходатайства о помиловании, что дает основания предполагать, что авторы это группы писем на момент написания прошения являлись осужденными, то есть более всего нуждались в покровительстве и заступничестве. Согласно тексту писем, причины осуждения авторов были разными. Так, корреспонденты СРН - крестьяне Волынской губернии были осуждены в связи с составлением ложных доносов на священника своего прихода. Они писали о том, что «сущность предъявленного нам по обвинительному акту обвинения заключается в том, что по предварительному между собой уговору, с целью навлечь на Священника Коркушко уголовное преследование, составили от имени крестьян два прошения, в которых заведомо ложно обвиняли Священника Коркушко в государственных преступлениях. Не отрицая того, что такие жалобы действительно нами поданы, отрицаем злой умысел в подаче этих жалоб. Мы были введены в заблуждение другими лицами» ${ }^{17}$.

Крестьяне Саратовской губернии были обвинены в нанесении односельчанину ножевых ранений «в состоянии запальчивости и раздражения»,

\footnotetext{
${ }^{15}$ ГА РФ. Ф. 116. Оп. 1. Д. 620, Л. 16.

${ }^{16}$ ГА РФ. Ф. 116. Оп. 1. Д. 35. Л. 281.

${ }^{17}$ ГА РФ. Ф. 116. Оп. 1. Д. 36. Л. 213.
} 


\section{Политика и общество 8 (116) • 2014}

вины своей не признают, инцидент объясняют ссорой, возникшей из-за расхождения во взглядах, а также тем, что это была самооборона и «обвинитель и его сообщники как революционеры показали на нас ложь», так как обвиняемые являются членами $\mathrm{CPH}^{18}$.

Часть крестьян-осуждённых, несмотря на то, что указывали свою принадлежность к этому сословию, служили писарями и служащими железных дорог. Крестьяне-писари обращались в Союз сообщали, что «состоя по вольному найму в должности писца и по злобе своего сослуживца» были оклеветаны в получении взяток. По этому факту было возбуждено уголовное преследование, в итоге которого был вынесен «к заключению в исправительное арестантское отделение на один год по лишении прав» ${ }^{19}$. Своей вины не признают, утверждая, что вели «против революционеров огромные дела, даже не дорожа жизнью своею, стоя за Царя, Веру и Отечество» и готовы «опять биться против революционеров до капли крови лишь бы сняли позор, наложенный ими» ${ }^{20}$.

Не все послания со стороны крестьян-осужденных носили экономический или уголовный характер, встречаются и ходатайства о помиловании со стороны осуждённых по политическим делам. Так, крестьянин-служащий Риго-Орловской железной дороги был осужден за участие в революционных забастовках. Неправомочность своих действий он признает, «раскаивается в своем невольном заблуждении». Однако он не считает себя виновным, «возлагая вину на авторитетных сослуживцев, которые воспользовались его слабой волей и абсолютным непониманием преступности задуманного» ${ }^{21}$.

В связи с этим встает вопрос об аутентичном и критичном прочтении писем и информации содержащейся в них: насколько так называемые «осужденные за революционные деяния» действительно по своим убеждениям относились к монархистам и можно ли причислять их к людям, разделяющим монархические воззрения, то есть поддерживающих СРН, или же их прошения были составлены с целью получить поддержку от СРН, рассчитывая на близость этой партии к власти и, таким образом,

\footnotetext{
${ }^{18}$ ГА РФ. Ф. 116. Оп. 1. Д. 35. Л. 293.

${ }^{19}$ ГА РФ. Ф. 116. Оп. 1. Д. 36. Л. 122.

${ }^{20}$ ГА РФ. Ф. 116. Оп. 1. Д. 35. Л. 161.

${ }^{21}$ ГА РФ. Ф. 116. Оп. 1. Д. 35. Л. 228.
}

возможность повлиять на смягчение приговора через властные структуры.

Ряд писем, составленных крестьянами, являлись прошениями об устройстве храмов и школ. В Главный совет СРН эти письма были направлены крестьянами-переселенцами, покинувшими в ходе аграрной реформы П.А. Столыпина свое предыдущее место жительство. На новом месте хотели эти крестьяне построить храм, в связи с чем они и обращались в СРН. В частности, они писали, что «бывшие жители российских губерний переселились в Акмолинскую область вблизи некрещенного племени киргизов», церкви в селении нет, строительство было разрешено, однако только на собственные средства. Переселенцы обратились за ссудой в Переселенческий комитет, в ссуде было отказано. Подали прошение в Главное Переселенческое управление, но ответа не получили. Просят походатайствовать о выдаче ссуды: «не найдётся ли возможность оказать нам помощь от СРН ради Покрова Божьей Матери, чтобы нам не остаться осмеянными киргизами и не посрамить своей религии. Заступитесь за нас бедных переселенцев» ${ }^{22}$. Такие письма интересны тем, что отражают новые условия жизни крестьян, раскрывая перед потомками малоизвестные страницы истории.

Часть писем имели основной целью просить через СРН получения личной аудиенции у Императора или выражали верноподданнические чувства. Это свидетельствует о том, что они отождествляли Союз с одной из верхних ступеней власти, или даже рассматривали его как рупор правительства, как канал, осуществляющий связь с царем. Так, крестьяне Ярославской губернии писали в СРН, но обращались непосредственно к Николаю II со следующими словами: «Просим тебя Великий Государь принять от нас сию простую грамоту и благодарность Вам от нас простого народа. < ..> До нас доходят нехорошие слухи о том, что есть люди, которые хотят уговорить тебя, чтобы ты Государь отрекся от власти самодержавной. Злые эти слухи снесут в страну твою великое горе. Просим вас, Императорское Величество, не отступится от нас простого народа и всегда быть покровителем и заступником нашим и избавителем от злых людей, не преклоняющихся твоей самодержавной власти. Мы всегда готовы повиноваться твоему зову и собраться как во-

${ }^{22}$ ГА РФ. Ф. 116. Оп. 1. Д. 36. Л. 43. 
ины собираются под знамя Великого Вождя и мы всегда готовы быть у ног твоих Государь. Государь, ты помазанник Божий, не отступись от нас серого народа» ${ }^{23}$. Монархическими настроениями проникнуто письмо от крестьян Костромской губернии, просивших Императора «не уступать требованиям твоих и наших врагов и не умолять Свои Права Самодержца» ${ }^{24}$, обещали в письмах «служить верой и правдой до последней капли крови за Веру, Царя и Отечество и на пользу Союзу» ${ }^{25}$. Это примеры говорят о том, что крестьяне, писавшие в СРН, разделяли и активно транслировали монархические воззрения через свои послания.

Кроме того, многие письма содержат как националистические, так и антиреволюционные высказывания. Так, например, крестьянин из Украины просил А.И. Дубровина ходатайствовать «перед Государем Императором о введении в действие существовавшего еще при Александре II и почему то отмененного закона о предупреждении и пресечении преступлений по которому жид, нанявший прислугу христианской веры, уплачивал штраф по 3 рубля в сутки. Пока был этот закон, не было такого разврата и подрыва Православной веры» ${ }^{26}$. Примером антиреволюционных настроений может случить письмо крестьянина, проживающего в области Войска Донского, в адрес А.И. Дубровина, датированное 1910 г., в котором он просил о помощи «бедным обездоленным труженикам, в святом деле, на благо нашего многострадального отечества, выбраться из революционной крамолы». Далее он сообщал, что «в области Войска Донского народу много нравственного: казаки, малороссы, великороссы, но много и заграничного: бельгийцев, французов, немцев, итальянцев, англичан и других. Даже есть жидовствующие. Заграничные люди занимают высшие должности. Было бы хорошо если бы на рудниках открылись отделы СРН для обуздания разных противоречий» ${ }^{27}$.

Ряд писем помимо основной просьбы содержали просьбы личного характера. Так, крестьянин Варшавской губернии, обращаясь к
А.И. Дубровину, писало «счастье записаться в Союз» и при этом просил «отказать быть крестным отцом моей новорожденной дочери» ${ }^{28}$. Что характерно, на письме содержится резолюция, написанная от руки и, судя по подписи, принадлежащая лично председателю СРН, в которой он выражал согласие стать крестным отцом и дал распоряжение приобрести крестик по случаю этого события.

Таким образом, крестьяне видели в СРН поддержку, способную помочь им в решении насущных проблем и вопросов, а также разделяли убеждения и взгляды Союза. То, как эти взгляды отражались в крестьянском сознании, можно наблюдать, изучая комплекс писем. Зачастую крестьяне идеализировали СРН и переоценивали роль и силу его лидеров в политике. Отдельно следует отметить лояльное отношение авторов писем к крайне правым - в архивном фонде не отложилось ни одного письма, содержащего осуждение или демонстрирующего разочарование в Союзе. Интересен тот факт, что крестьяне были наиболее активной и многочисленной группой корреспондентов по сравнению с представителями других социальных слоев российского общества начала XX в. Анализ посланий в Главный совет СРН и редакцию газеты «Русское знамя» позволяет говорить о том, что крестьяне после революции 1905-1907 гг. сохраняли монархические установки и разделяли идеи крайне правого политического движения. Среди них выделим безусловную поддержку самодержавия, антиреволюционные воззрения, националистические, в особенности, антисемитские настроения. Реконструкция содержания массового сознания крестьян в период первой российской революции может быть продолжена и в других ракурсах и аспектах, материалы архивного фонда Союза русского народа дают широкие возможности для исследователей крестьянской ментальности, ее структуры, содержания, а также развития в первое десятилетие XX в.

\footnotetext{
${ }^{23}$ ГА РФ. Ф. 116. Оп. 1. Д. 36. Л. 133.

${ }^{24}$ ГА РФ. Ф. 116. Оп. 1. Д. 35. Л. 22.

${ }^{25}$ ГА РФ. Ф. 116. Оп. 1. Д. 604. Л. 38.

${ }^{26}$ ГА РФ. Ф. 116. Оп. 1. Д. 625, Л. 109.

${ }^{27}$ ГА РФ. Ф. 116. Оп. 1. Д. 35. Л. 99.
}

${ }^{28}$ ГА РФ. Ф. 116. Оп. 1. Д. 604. Л. 14. 


\section{Политика и общество $8(116) \cdot 2014$}

\section{Библиография:}

1. Буховец О.Г. Социальные конфликты и крестьянская ментальность в Российской империи начала ХХ века: новые материалы, методы, результаты. М., 1996.

2. Громыко М.М. Мир русской деревни. М., 1991.

3. Гуревич А.Я. Проблема ментальностей в современной историографии // Всеобщая история: Дискуссии, новые подходы. Вып. 1. М., 1989.

4. Касьянова К. О русском национальном характере. М., 1994.

5. Кирьянов Ю.И Русское собрание 1900-1917 гг. М., 2003.

6. Кирьянов Ю.И. Правые партии в России 1911-1917. М., 2001.

7. Ключевский В.О. Афоризмы. Исторические портреты и этюды. Дневники. М., 1993.

8. Менталитет и аграрное развитие России (ХІХ-ХХ вв.). М., 1996.

9. Менталитет и политическое развитие России. М., 1996.

10. Морозов Н. Менталитет русских: понятие, структура // Вестник российской нации. 2012. Т.1. Вып. 21. С. 67-88 .

11. Омельянчук И.В. Черносотенное движение в Российской империи (1901-1914). Киев, 2006.

12. Революция и человек. Социально-психологический аспект. М., 1996.

13. Революция и человек: быт, нравы, поведение, мораль. М., 1997.

14. Русский консерватизм середины XVIII-начала XX века : энциклопедия. М., 2010.

15. Селунская Н.Б., Тоштендаль Р. Зарождение демократической культуры в России: Россия в начале ХХ века. М., 2005.

16. Степанов С.А. Чёрная сотня в России (1905-1914). М., 1992.

17. Безгин В.Б. Русская деревня конца XIX - начала XX века: грани крестьянской девиантности (Часть 1). // NB: Исторические исследования. - 2012. - 1. - С. 120 - 167. DOI: 10.7256/2306-420X.2012.1.266. URL: http://www.e-notabene. $\mathrm{ru} / \mathrm{hr} /$ article $266 . \mathrm{html}$

18. Безгин В.Б. Сельское общественное управление и его представители в оценке русских крестьян (вторая половина XIX - начало XX века) // NB: Вопросы права и политики. - 2013. - 2. - C. 155 - 192. URL: http://www.e-notabene. ru/lr/article_514.html

19. Безгин В.Б. Русская деревня конца XIX - начала XX века: грани крестьянской девиантности (Часть 2) // NB: Исторические исследования. - 2012. - 2. - С. 149 - 190. DOI: 10.7256/2306-420X.2012.2.302. URL: http://www.e-notabene.ru/hr/article 302.html

20. С. А. Февралёв Местное законодательство в государственно-правовом развитии России (вторая половина XVII начало ХХ вв.) // Право и политика. - 2011. - 7. - С. $1171-1181$.

21. С. А. Февралёв Политико-юридическая природа местного права в Российской империи (вторая половина XVII начало ХХ вв.). // Право и политика. - 2012. - 2. - С. 327 - 338.

22. К. А. Пахалюк Идеологические причины делегитимизации самодержавия в России // Исторический журнал: научные исследования. - 2012. - 5. - С. 45 - 52.

23. Кодан С.В., Февралёв С.А. Местное право национальных регионов Российской Империи: истоки, место в политике и идеологии, юридическая природа (вторая половина XVII - начало XX вв.) // NB: Вопросы права и политики. - 2013. - 2. - C. 74 - 154. URL: http://www.e-notabene.ru/lr/article 464.html

\section{References (transliteration):}

1. Bukhovets O.G. Sotsial'nye konflikty i krest'yanskaya mental'nost' v Rossiiskoi imperii nachala XX veka: novye materialy, metody, rezul'taty. M., 1996.

2. Gromyko M.M. Mir russkoi derevni. M., 1991.

3. Gurevich A.Ya. Problema mental'nostei v sovremennoi istoriografii // Vseobshchaya istoriya: Diskussii, novye podkhody. Vyp. 1. M., 1989.

4. Kas'yanova K. O russkom natsional'nom kharaktere. M., 1994.

5. Kir'yanov Yu.I Russkoe sobranie 1900-1917 gg. M., 2003.

6. Kir'yanov Yu.I. Pravye partii v Rossii 1911-1917. M., 2001

7. Klyuchevskii V.O. Aforizmy. Istoricheskie portrety i etyudy. Dnevniki. M., 1993.

8. Morozov N. Mentalitet russkikh: ponyatie, struktura // Vestnik rossiiskoi natsii. 2012. T.1. Vyp. 21. S. 67-88 .

9. Omel'yanchuk I.V. Chernosotennoe dvizhenie v Rossiiskoi imperii (1901-1914). Kiev, 2006.

10. Selunskaya N.B., Toshtendal' R. Zarozhdenie demokraticheskoi kul'tury v Rossii: Rossiya v nachale KhKh veka. M., 2005.

11. Stepanov S.A. Chernaya sotnya v Rossii (1905-1914). M., 1992.

12. Bezgin V.B. Russkaya derevnya kontsa XIX - nachala XX veka: grani krest'yanskoi deviantnosti (Chast' 1). // NB: Istoricheskie issledovaniya. - 2012. - 1. - C. 120 - 167. DOI: 10.7256/2306-420X.2012.1.266. URL: http://www.e-notabene.ru/hr/article_266.html 
13. Bezgin V.B. Sel' 'skoe obshchestvennoe upravlenie i ego predstaviteli v otsenke russkikh krest' yan (vtoraya polovina XIX - nachalo XX veka) // NB: Voprosy prava i politiki. - 2013. - 2. - C. 155 - 192. URL: http://www.e-notabene.ru/lr/article_514.html

14. Bezgin V.B. Russkaya derevnya kontsa XIX - nachala XX veka: grani krest' yanskoi deviantnosti (Chast' 2) // NB: Istoricheskie issledovaniya. - 2012. - 2. - C. 149 - 190. DOI: 10.7256/2306-420X.2012.2.302. URL: http://www.e-notabene.ru/hr/article_302.html

15. S. A. Fevralev Mestnoe zakonodatel'stvo v gosudarstvenno-pravovom razvitii Rossii (vtoraya polovina XVII - nachalo XX vv.) // Pravo i politika. - 2011. - 7. - C. 1171 - 1181.

16. S. A. Fevralev Politiko-yuridicheskaya priroda mestnogo prava v Rossiiskoi imperii (vtoraya polovina XVII - nachalo XX vv.). // Pravo i politika. - 2012. - 2. - C. 327 - 338.

17. K. A. Pakhalyuk Ideologicheskie prichiny delegitimizatsii samoderzhaviya v Rossii // Istoricheskii zhurnal: nauchnye issledovaniya. - 2012. - 5. - C. $45-52$.

18. Kodan S.V., Fevralev S.A. Mestnoe pravo natsional' 'nykh regionov Rossiiskoi Imperii: istoki, mesto v politike i ideologii, yuridicheskaya priroda (vtoraya polovina XVII - nachalo XX vv.) // NB: Voprosy prava i politiki. - 2013. - 2. - C. 74 154. URL: http://www.e-notabene.ru/lr/article_464.html 